\title{
The Choice of the School Manager in the Brazilian Public Networks: On the Concept of Democratic Management of Teaching
}

\author{
Rosimar Serena Siqueira Esquinsani, Valdocir Antonio Esquinsani \\ University of Passo Fundo/UPF_-Passo Fundo, Rio Grande do Sul, Brazil \\ Email: rosimaresquinsani@upf.br
}

How to cite this paper: Esquinsani, R. S. S., \& Esquinsani, V. A. (2017). The Choice of the School Manager in the Brazilian Public Networks: On the Concept of Democratic Management of Teaching. Creative Education, 8, 1424-1432.

https://doi.org/10.4236/ce.2017.89100

Received: April 22, 2017

Accepted: July 24, 2017

Published: July 27, 2017

Copyright ( 92017 by authors and Scientific Research Publishing Inc. This work is licensed under the Creative Commons Attribution International License (CC BY 4.0).

http://creativecommons.org/licenses/by/4.0/

\begin{abstract}
The text reflects on the principle of the "democratic management of public education", established in the Brazilian Federal Constitution, verifying how the materialization of this principle occurs in state legislations. For this, it analyzes the laws on the process of choosing the position of school manager in the state public networks of the 26 Brazilian states and the Federal District (considering their equivalent status as federated entity), identifying relations between legislations, the choice of the manager and the Materiality of the principle of democratic management of public.
\end{abstract}

\section{Keywords}

School Manager, Public Network, Democratic Management, Brazil

The Brazilian Federal Constitution of 1988 describes eight principles for the teaching in the country (article 206), among them the principle of "democratic management of public teaching, in the form of the law" (section IV). However, predicting this principle is not sufficient to indicate what "democratic management" because on this principle different interpretations are possible, since...

The maintenance of the democratic management of public teaching, at the same time as it was configured as a conquest by the segments committed to the democratization of education management, represented a partial achievement, inasmuch as its scope was limited and its operationalization delegated to future regulations, which meant that its applicability was delayed. Moreover, the idea of democratic management of teaching received no further reference, none throughout the constitutional text. (Adrião \& Camargo, 2002: p. 74) 
At a later stage the principle of "democratic management" - as one of the pillars of national public teaching - was repeated in other legislation, especially in the Law on Guidelines and Bases of National Education number 9394/96 in Art. 3, section VIII and Art. 14 of the same law. However ...

... although there are references and principles of democratic management and the quality of public teaching in the Federal Constitution and most recent in the Law on Guidelines and Bases of National Education, these legal provisions stumble $[. .$.$] at failure to describe and define more accurately$ mechanisms that guarantee educational administration actions actually more democratic. (Passador \& Salvetti, 2013: p. 480)

This is because the legislation is not descriptive, does not explicitly relate mechanisms or actions that guarantee democratic management, leaving open the debate on the concept and mechanisms of what would be a democratic management.

It is necessary, then, to materialize mechanisms and actions that guarantee a democratic management of the teaching. At National Plan for the EducationLaw 13,005/2014-, the principle of democratic management figure explicitly to two articles: Art. 2, section VI and Art. 9, requiring measures to each federated state regarding the regulation of specific laws for the treatment of the subject:

The states, the Federal District and the municipalities must approve specific laws for their teaching systems, disciplining the democratic management of public teaching in their respective fields of performance, within two (2) years from the publication of this Law (Brazil, 2014).

This latest legislation-the National Plan for the Education-calls for the need to regulate the issue, urging states and municipalities to discuss mechanisms for democratic management.

Based on the lack of a legal and national description of what is "democratic management", the text reflects the principle of democratic management and its materialization in regional legislations, based on the examination of the laws on the election of directors in the public networks of the 26 states Brazilians and the Federal District (considering their equivalent federated status). In the examination carried out, it seeks to identify possible relations between the forms of provision and the materiality of the principle of democratic management.

The theme of "choice of school managers" in schools in the public system is the subject of specific and regional legislation. Each public system can freely adopt one of the basic forms of access to the post, as long as it is regulated in its legislation.

The literature on the area of educational administration has highlighted the possibility of four basic forms of access to the position of school manager: the appointment; the public tender; Election and the mixed regime (Gadotti \& Romão, 2004). In the same line of reasoning, Dourado (2006: p. 64), informs that the choice of managers can be made by: a) free indication by the public power; b) career director; c) director approved in public competition; d) director 
appointed by the triple lists or, e) direct election of the director.

\section{About the Empirical Data}

For the elaboration of the article a qualitative/quantitative methodology was used with an analytical-reconstructive focus, developed within three approaches: the collection of quantitative data from regional legislations on the theme "democratic management of teaching"; the content analysis procedure in selected regional legislations and, lastly, a thematic bibliographic review.

The regional legislation was examined from the content analysis procedure, using the thematic analysis technique, where the "[...] theme is the unit of meaning that is freed naturally from a text analyzed, according to criteria related to the theory that serves as guide to reading" (Bardin, 2007: p. 105).

The analysis material was constituted from the meeting of regional laws circumscribed to 26 Brazilian states and the Federal District, with the theme of electing directors and/or the democratic management of the state public network. It is understood that such legislations are historical and contextual, so they are not "a finished product, but a moment in a process of elaboration" (Bardin, 2007: p. 164) (Table 1).

Table 1. State legislations on choice the office of school manager.

\begin{tabular}{|c|c|}
\hline $\begin{array}{l}\text { Federation } \\
\text { unity brasilian }\end{array}$ & Legislation \\
\hline Acre & $\begin{array}{l}\text { Law No. } 1513 \text {, dated } 11 / 11 / 2003 \text {, which provides for the democratic management of the public education system in the state of } \\
\text { Acre and provides other measures. Source: http://www.al.ac.leg.br/leis/?p=5558 }\end{array}$ \\
\hline Alagoas & $\begin{array}{l}\text { Ordinance No. } 6628 \text {, of October } 21,2005 \text {, which establishes new rules for management in the state public school system, as a } \\
\text { space for participation and collective construction, through new directives regarding the direct elections for director and } \\
\text { deputy director of schools of Basic education, and other measures - DOE of October 24, 2005, regulated by Decree } 2916 \\
\text { (November } 24,2005 \text { ), amended by Decree } 4.033 \text { (July 18,2008). } \\
\text { Source: http://www.educacao.al.gov.br/legislacao-1/leis/2005-1/lei_6628_2005.pdf }\end{array}$ \\
\hline Amapá & $\begin{array}{l}\text { Law No. } 1503 \text {, dated 9/7/2010, which provides for the regulation of democratic school management in the school units of the } \\
\text { state educational system. Source: http://www.al.ap.gov.br/ver_texto_lei.php?iddocumento=25541 }\end{array}$ \\
\hline Amazonas & $\begin{array}{l}\text { General Rules of the State Schools of Amazonas_Resolution } n^{\circ} .122 / 2010-E E C / A M \text {, adopted on 30.11.2010. Source: } \\
\text { http://www.cee.am.gov.br/index.php?option=com_phocadownload\&view=category\&download=162:2010\&id=21:2010\&Itemid } \\
\underline{\underline{194}}\end{array}$ \\
\hline Bahia & $\begin{array}{l}\text { Decree } \mathrm{n}^{\circ} 13.202 \text {, dated } 8 / 19 / 2011 \text {, which regulates art. } 18 \text { of Law No. } 8261 \text {, of May } 29,2002 \text {, providing for the criteria and } \\
\text { procedures of the internal selection process to be carried out by the school unit, a requirement for filling the positions of } \\
\text { director and deputy director of school units in the state of Bahia, And other measures }\end{array}$ \\
\hline Ceará & $\begin{array}{l}\text { Law no. 13. 513, dated July } 19,2004 \text {, which provides for the process of choosing and indicating for the position of appointment } \\
\text { in a commission of director next to the schools of the state public school of education, and makes other provisions. } \\
\text { Source: https://www.al.ce.gov.br/legislativo/tramitando/lei/13513.htm }\end{array}$ \\
\hline Distrito Federal & $\begin{array}{l}\text { Law No. } 4.751 \text {, dated 7/2/2012, which provides for the education system and democratic management of the public education } \\
\text { system of the Federal District. Ordinance No. } 254 \text { of October 1, } 2013 \text {. } \\
\text { Source: http://www.tc.df.gov.br/SINJ/Arquivo.ashx?id_norma_consolidado=70523 }\end{array}$ \\
\hline Espirito Santo & $\begin{array}{l}\text { Complementary Law No. } 115 \text { Establishes the Statute of the State Public Magisterium, of January 13, } 1998 . \\
\text { Source: http://www.al.es.gov.br/antigo_portal_ales/images/leis/html/LC\%20115.html }\end{array}$ \\
\hline Goiás & $\begin{array}{l}\text { Law No. 13,564, of December 8, 1999, which establishes criteria for the process of election of directors of public schools, as } \\
\text { amended by Law No. 14,340, dated 12.3.2002 and by Decree No. } 6647 \text { of December 31, 1999-07-2007 } \\
\text { Source: http://www.gabinetecivil.go.gov.br/leis_ordinarias/2002/lei_14340.htm }\end{array}$ \\
\hline
\end{tabular}




\section{Continued}

Maranhão

Law No. 9860, dated July 1, 2013. It provides for the Statute and the Career, Charge and Compensation Plan of the members of the Basic Education Magisterial Subgroup (articles 60 and 61), ratified by Law 10,099 of June 11 Of 2014, which approves the State Plan of Education of the State of Maranhão

Law No. 7.040, dated 10/10/1998, which regulates the provisions of art. 14 of Federal Law 9394 of December 20, 1996, as well as item VI of art. 206 of the Federal Constitution, which establish democratic management of state public education, adopting the selective system to choose the leaders of educational establishments and the creation of deliberative councils of the school community in educational units.

Mato Grosso Law No. 3.244, dated 6/6/2006, which provides for the election of directors, deputy directors and the school collegiate of the do Sul state education network of Mato Grosso do Sul, and makes other provisions.

Minas Gerais

Resolution State Secretary of Education No. 1812 of March 22, 2011

Source: https://www.educacao.mg.gov.br/images/stories/noticias/resolucao-see-n.o-1812.pdf

Pará

Decree No. 695 of March 26, 2013, which establishes criteria for the exercise of the functions of directors and vice-principals of the schools of the state education network to be adopted by the State Department of Education and provides other measures. Law $n^{\circ} 7855$, of May 14, 2014.

Paraíba Law 7.983, of April 10, 2006, complemented by Law 8.294, of August 16, 2007, made without effect by decision of the TJPB, on September 19, 2016. Source: https://app.tjpb.jus.br/dje/rest/ultimosdiarios/diario/20_09_2016.pdf

Law No. 18.590, dated 13/12/2015 - Definition of selection criteria through consultation with the School Community for the Paraná appointment of Directors and Auxiliary Directors of the State Basic Education Network of Paraná. Source: http://www.legislacao.pr.gov.br/legislacao/

Piauí

Decree 14,607 of October 14, 2011, which regulates article 119 of Complementary Law No. 71, of July 26, 2006, disciplining the process of choosing school principals from the state public school system in Piauí, and gives other measures.

Pernambuco

Decree $\mathrm{n}^{\circ}$ 38.103, dated April 25, 2012, which regulates the criteria and procedures for conducting a selection process for the function of representation of school director and deputy director of state schools and other measures.

Rio de Janeiro Law 7299, dated June 6, 2016. Source: http://alerjln1.alerj.rj.gov.br/

Rio Grande do

Supplementary Law No. 290, dated 2/16/2005, which provides for the democratization of school management within the public Norte August 2005.

Rio Grande do Law 10,576 of November 14, 1995, which provides for the democratic management of public education, updated to Law 13,990 Sul of May 15, 2012. Source: http://servicos.educacao.rs.gov.br/dados/lei_10.576_compilado.pdf Deputy Director of Schools of the State Public School Network of Rondônia and other measures - DOE N. 1820 of September 20,2011

Complementary Law No. 041 of July 16, 2001-Provides for the State System of Education of the State of Roraima; Law No. Roraima 810 of July 6, 2011-Provides for the reorganization of the School Councils of the State Educational System; Source: http://www.mpc.rr.gov.br/uploads/2013/09/0309201302075572_6.pdf

Santa Catarina Supplementary Law No. 170, of August 07, 1998-Provides for the State Educational System.

Source: http://www.sed.sc.gov.br/documentos/legislacao-eja/4496-lei-complementar-170-98-sistema-estadual-de-sc/file

São Paulo Complementary Law No. 1256, dated January 6, 2015; Complementary Law No. 1207, of July 5, 2013.

Source: http://www.al.sp.gov.br/repositorio/legislacao/lei.complementar/2015/lei.complementar-1256-06.01.2015.html

Decree 16,396 of March 20, 1997-Provides regulatory norms on a democratization of the management of public education, in

Sergipe accordance with Articles 171 and 172 of Complementary Law No. 16/94, and provides related provisions.

Source: $\underline{\text { http://seed.se.gov.br/arquivos/Decreto_16.396_20-03-1997.pdf }}$

Law No. 2977, of July 8, 2015. Published in Official Gazette 4411, approves the State Education Plan of Tocantins-PEE/TO (2015-2025), in the process of regulation through EDITAL $N^{\circ}$ 0058/2015-Provides On the Process of Effectiveness of

Tocantins Democratic Management in the State Public School Network of Tocantins, according to the criteria of technical-professional competencies, for the function of Director of School Unit. DOE no. 4.510 Tuesday, 1/12/2015.

Source: http://www.al.to.leg.br/arquivo/38073

Source: author's organization, based on various internet sites and also on Gomes, 2015 
We began by collecting and cataloging 27 regional laws (from the 26 Brazilian states and the Federal District)—written between 1995 and 2016-referring to public education systems. Each law was searched in different places-on official state pages or on search sites. Next, we separate and highlight the issue of "democratic management" in each of the laws.

According to Gadotti \& Romão, 2004, the process of democratic choice of school managers began in the 1960s in the state of Rio Grande do Sul. The pioneerism of this state also occurs in relation to the legislation on "democratic management", being from the state of Rio Grande do Sul to the oldest law on the subject: 1995.

Of the 27 legal documents examined, 10 legislations specifically mention the choice of school manager as a synonym for democratic management. Other 09 laws are called "democratic management laws". The other eight laws that make up the framework of analysis are quite broad: laws of state education plans, or documents that regulate existing laws.

In the sequence was made a critical reading of all the legislations selected, from which we developed the discussions on the choice of school management and the relation of this choice to "democratic management".

\section{About the Detailed Discussions}

On the form of choice of school management, based on the scheme proposed by Gadotti \& Romão, 2004, the legislations mapped present the following discussion: of the 27 laws analyzed, 02 present a choice of school managers by mixed scheme (which merges two or more of the forms described); 01 exclusively by public tender; 03 by express indication of the state executive and 21 laws affirm a choice of the managers of the state schools through the election of directors.

For this data alone, we can interpret that most Brazilian states identify "elections of manager" as synonymous with "democratic management" of teaching, guaranteeing this action in their regional legislations.

Nonetheless, in the legislations examined, in addition to the logistical details in the processes of provision, it is possible to recognize two themes that underline the democratic management of public teaching, besides the form of filling the position of school director: a) the description of the concept of democratic management and, b) the description of other mechanisms and instances that would ensure democratic management.

Several laws seek to conceptualize democratic management as a continuous process, which implies in several actions. We have, for example, a relevant concept outlined in the legislation of the state of Acre:

Art. $1^{\circ}$. It is understood by democratic management the intentional and systematic process of arriving at a decision and making it work, mobilizing means and procedures to achieve the objectives of the school institution, involving the pedagogical, technical-administrative and managerial aspects of the process (ACRE, Law No. 1513/2003). 
A little less detailed, but equally incisive, the description of democratic management in the state network of Sergipe provides that "Art. $2^{\circ}$. The democratization of the management of the state public school consists of the participation of the internal and external communities, in a representative way, in the collegial decisions" (SERGIPE, Decree 16.396/1997).

The legislation of the state of Roraima is more descriptive and detailed, involving in the concept of democratic management of public teaching, aspects such as planning and evaluation:

Art. 18. The democratic management of public education, understood as collective action and political-philosophical practice, will guide all planning, formulation and evaluation of educational policies and will reach all entities and organizations that are part of the State Educational System (RORAIMA, Complementary Law No. 041/2001).

Likewise, the legislation of the State of Espírito Santo does not restrict the concept of "democratic management" to the choice of directors by means of elections, but indicates that it is the participation of all that guarantees democratic management in practice:

Art. 45. The State public schools shall obey the principle of democratic management through: I-participation of education professionals, students, parents, servants and representatives of local popular organizations, in the composition of School Council, normative and deliberative bodies, as well as in the process of election of its directors, including these the director, the assistant director and the school coordinator (ESPÍRITO SANTO, Complementary Law $n^{\circ} 115 / 1998$ )

The examination of regional laws still allows us to perceive: 1) the spaces and institutions that can guarantee democratic management, and 2) the formal prohibition of possibly contrary practices to democratic management.

In relation to the spaces and institutions that can guarantee democratic management, the legislations especially point out the existence and strengthening of joint councils such as the School Council. The School Council is a body of internal school control and management, composed of representatives of parents, students, teachers and staff.

However, the work of joint elaboration of the pedagogical project of the school also takes on importance as mechanisms of democratic management, as highlighted in the Tocantins state law, which seeks to guarantee the pedagogical autonomy of schools as a way to also ensure the management of democracy (TOCANTINS, Law no. 2977/2015).

As for the second perception-or the law as a way of prohibiting practices contrary to democratic management-it is important to establish that every law is always contextual and historical, supposedly reflecting concrete and everyday situations and the need to regulate them or predict their occurrence.

Thus, we have some legal considerations that are outside the scope of a state law. Such considerations mention, for example, details about the everyday life of 
schools (and this need not be the subject of state law), but the need to regulate these everyday details may be the result of some contextual practices that may occur in educational networks. The lawmakers in the state of Acre, for example, found it relevant to regulate the working hours of public agents involved in school management. The law says: "Art. 41. The education coordinator must complete two shifts at school, that allows its presence in all shifts of operation of the teaching unit" (ACRE, Law 1513/2003).

Another example comes from the state of Alagoas, where there are regulations prohibiting the exchange successive of positions for reelections: "Art. 2, paragraph 1-The members of the Magisterium re-elected to positions of General Director and Deputy Director can not participate in another elective process, regardless of the position occupied in a minimum period of two (2) years" (ALAGOAS, Ordinance 6628/2005). From these findings, we can draw two conclusions. On the one hand, since a law is the result of actual or potential situations, a simplistic analysis leads us to indicate that practices similar to those described in the legislation may occur at some point and therefore should be prohibited by law.

On the other hand, we can understand besides the election of directors, other the mechanisms of democratic management are also considered: a) greater permanence of the director in the school, interacting with the school community and b) exchange of personnel in managerial positions, allowing changes in leadership.

\section{Other Discussions}

When we look at the choice of the school principal, we are not simply investigating an administrative matter, but rather researching one of the mechanisms to discuss important concepts in the field of school management, particularly the concept of democracy in education. And allowing the community to freely choose its director has been a practice that reinforces democracy in school.

Thus, it seems opportune to indicate that the most relevant discussion about the research presented is about the practices and mechanisms that can effectively guarantee democratic management.

The concept of democratic management can be explained as follows:

... political process in which the people who work in the school identify problems, discuss, deliberate and plan, direct, monitor, control and evaluate the set of actions aimed at the development of the school itself in the search for the solution of those problems. This process, based on dialogue, alterity and recognition of the technical specificities of the various functions present in the school, is based on the effective participation of all segments of the school community, respect for the collectively constructed norms for decision-making processes and the guarantee of broad access to information for the subjects of the school. (Souza, 2009: pp. 125-126)

Therefore, as the school principal is chosen-although important-should be 
added to other practices in building the concept of democratic management. The director's choice is a path to democratic management, not synonymous with the management of democracy itself. Thus, it is considered...

... as principle of struggle for effective autonomy, understood as the capacity of one people to self-govern. The effectiveness of this process of democratization of public school management implies, therefore, the sharing of power, the sensitivity to lead the school, from the demands of the school community, and the decision making and responsible and collective choices.

(Dourado, 2006: p. 46)

We emphasize, therefore, that the different ways of choosing the school manager are 'one of the' management mechanisms of the public school. If the choice is by direct election, for example, it will be characterized explicitly as a mechanism of democracy.

The school is not democratizable simply by the democratization of its organizational and management structures, nor only by the election of directors or other responsible ones; School access and success, pedagogy, curriculum and assessment, organization of work in school, a public school as a place of work, their forms of civic and socio-cultural intervention with the community, represent, among others, Elements that depend also on this democratization (Lima, 2002: p. 46).

The legislations examined seem to indicate that there is an understanding of the similarity between democracy and election of directors. That is, more democratic will be the public network that guarantees free elections for school directors.

Many laws are already changing. Partly due to the force of Law 13,004 of 2015, partly due to the need for adjustment. But the direct link between elections for directors and democratic management seems to persist.

However, such a mechanism does not have the strength to represent alone the totality of democracy, because "the election is the form of choice of school maangers more compatible with the struggle for a quality basic school and accessible to the greatest number of people" (Paro, 2003: p. 121).

\section{Conclusion}

There are different ways to choose the school manager in Brazil. There is no single consensus or model. Thus, there are several laws that discuss the subject in different spaces, including the laws of the public networks of the 26 states and Federal District.

The local legislation sets the tone of the debate: in the absence of a consensual, national, clear and specific concept of democratic management, each of the twenty-seven federated entities examined shows that it has found a formula for defining democratic management in its legislations.

The direct relationship between the election of directors and democratic management seems to have guided the legislations examined where, even in 
documents explicitly mentioning "democratic management", the main focus remains on the election of directors.

Most laws on the choice of directors in state education networks predate Law 13,005, 2014-the National Education Plan Act. Therefore, the states and the Federal District will, in a short time, review their legislation. It is assumed that there will be some changes in the legislation. However, there still seems to be a strong tendency to consider the choice of school managers through elections as synonymous with democracy in public networks.

Finally, the text emphasizes that the multifactorial character of educational management is even more prominent when viewed through the approach of choosing school principals in public networks of the Brazil, requiring constant discussions about the concept of "democratic management" and mechanisms guaranteeing practice this concept.

\section{References}

Adrião, T., \& Camargo, R. B. (2002). The Democratic Management in the Federal Constitution of 1988. In R. P. Oliveira, \& T. Adriâo (Orgs.), Information Management and the Right to Analyze the LDB and the Constitution (Federal 3rd ed., pp. 69-78). São Paulo: Shaman.

Bardin, L. (2007). Content Analysis (Editions 70). Lisbon: Trad. Luiz Antero Reto and Augusto Pinheiro.

Brazil (2014). Law 13,005. It Approves the National Education Plan-PNE and Gives Other Measures. Brasília: Civil House. http://www.planalto.gov.br/ccivil_03/_Ato2011-2014/2014/Lei/L13005.htm

Dourado, L. F. (2006). Management of School Education. Brasília: University of Brasília, Center for Distance Education.

Gadotti, M., \& Romão, J. E. (2004). School Autonomy: Principles and Proposals. São Paulo: Cortez Publisher: IPF.

Gomes, A. V. A. (2015). Democratic Management in the National Education Plan 20142024. In A. V. A. Gomes, \& T. F. de Britto (Org.), National Education Plan: Construction and Perspectives (293 p). Brasilia: Chamber of Deputies, Chamber Editions: Federal Senate, Technical Editions. (Series works in partnership, No. 8).

http://bd.camara.leg.br/bd/bitstream/handle/bdcamara/21659/plano_nacional_educaca o.pdf? sequence $=1$

Lima, L. (2002). School Organization and Radical Democracy: Paulo Freire and the Democratic Governance of the Public School (3rd ed.). São Paulo: Cortez.

Paro, V. H. (2003). Election of Directors: A Public School Experiences Democracy (2nd ed.). São Paulo: Shaman.

Passador, C. S., \& Salvetti, T. S. (2013). Democratic School Management and Critical Organizational Studies: Theoretical Convergences. Education and Society, 34, 477-492.

Souza, Â. R. de. (2009). Exploring and Building the Concept of Democratic School Management. Education in Journal. Belo Horizonte, 25, 123-140. 
Submit or recommend next manuscript to SCIRP and we will provide best service for you:

Accepting pre-submission inquiries through Email, Facebook, LinkedIn, Twitter, etc. A wide selection of journals (inclusive of 9 subjects, more than 200 journals)

Providing 24-hour high-quality service

User-friendly online submission system

Fair and swift peer-review system

Efficient typesetting and proofreading procedure

Display of the result of downloads and visits, as well as the number of cited articles Maximum dissemination of your research work

Submit your manuscript at: http://papersubmission.scirp.org/

Or contact ce@scirp.org 